\title{
First-year university students' productive knowledge of collocations
}

\author{
Déogratias Nizonkiza, Tobie van Dyk and Henk Louw \\ School of Languages, North-West University, Potchefstroom Campus, South Africa \\ E-mail: deo.nizonkiza@nwu.ac.za; tobie.vandyk@nwu.ac.za; henk.louw@nwu.ac.za
}

\begin{abstract}
The present study examines productive knowledge of collocations of tertiary-level secondlanguage (L2) learners of English in an attempt to make estimates of the size of their knowledge. Participants involved first-year students at North-West University who sat a collocation test modelled on that developed by Laufer and Nation (1999), with words selected from the 2000-, 3000-, and 5000-word bands (Nation 2006) and the Academic Word List (Coxhead 2000). The achieved scores were analysed in light of Schmitt's (2003, in Xing and Fulcher 2007) cut-off point for an acquired word-frequency band (80\%), as well as Nation's (1990) suggested threshold of productive knowledge at tertiary level (at least the 3,000 most frequently used words). Results indicate that the participants do not master the 3000-word band and therefore fall slightly short of expectations. Only the 2000 -word band is mastered by most of these firstyear student participants, with some of them not entirely mastering this band. On the basis of these results, pedagogical consequences are discussed in terms of how to help students reach the minimum threshold of productive knowledge that is needed to cope with the academic challenges at tertiary level.
\end{abstract}

Keywords: collocations, productive knowledge, word-frequency bands

\section{Introduction}

Research interest in vocabulary has risen substantially over the past three decades, with findings showing that vocabulary is an integral component of second-language (L2) or foreign-language (FL) proficiency (cf. Daller, Milton and Treffers-Daller 2007, Meara 2002, Zareva, Schwanenflugel and Nikolova 2005). Collocations, in particular, are important for L2 learners (Barfield and Gyllstad 2009), especially at the productive level (Boers, Eyckmans, Kappel, Stengers and Demecheleer 2006, Bonk 2001, Eyckmans 2009, Howarth 1998, Schmitt 1998). L2 learners' familiarity with collocations has been investigated on both the receptive level (Eyckmans 2009, Gyllstad 2007, 2009, Keshavarz and Salimi 2007) and the productive level (Boers et al. 2006, Bonk 2001, Eyckmans, Boers and Demecheleer 2004, Gitsaki 1999, Nizonkiza 2012b) by means of collocation tests. However, it is still unclear which is the best way to test collocations, since they are complex in nature and the studies that have been conducted on them seem to be entirely descriptive (Schmitt 1998). In addition, the different 
angles from which collocations have been researched may also explain why we still do not know how best to test them (Eyckmans 2009, Nesselhauf 2005). This view is supported by Daller et al. (2007), according to whom testing collocations is still unstandardised because of the lack of consensus as to how to characterise this knowledge.

Several attempts to test collocations have recently been made, which Gyllstad (2007) groups into two categories, namely corpus-driven studies and experimental studies. Corpus-driven studies analyse learners' essays in corpora, with attempts to make inventories of and categorise the errors produced by these learners (cf. Cowie 1998, Granger 1998, Granger and Paquot 2008, Howarth 1998, Laufer and Waldman 2011, Nesselhauf 2005). A common observation of these studies is that collocations cause difficulties for L2 learners even at an advanced level, and most errors are first-language (L1) related (Laufer and Waldman 2011, Nesselhauf 2005). This observation was confirmed by Louw (2005) in his study on the use of adverbial intensifiers which are frequently used in the adverb-verb collocation and are encouraged at tertiary level, especially for hedging purposes. He found that Tswana native speakers, who are L2 users of English, employed a substantially smaller range of adverbs in their writing than their English native-speaker counterparts.

Experimental studies, on the other hand, consist of both receptive and productive tests which measure how well learners perform. Bonk (2001), Eyckmans et al. (2004), Gitsaki (1999) and Nizonkiza (2012b) constitute typical examples of studies that tested productive knowledge of collocations. A finding common to these studies is that collocations develop in correlation with overall proficiency.

While these studies have produced interesting results and analyses with regard to the causes of collocation errors and their types, as well as the relationship between possessing knowledge of collocations and overall proficiency, what remains uninvestigated is the level of productive knowledge of collocations needed to function independently at tertiary level, let alone at other learning stages. In other words, no study has attempted to set a benchmark of collocational knowledge achieved or needed at tertiary level or other learning stages. This issue leaves a significant gap in the literature which needs to be addressed. The present study aims to bridge this gap by attempting to answer the following question: What is the extent of the productive knowledge of collocations of tertiary-level L2 users of English?

In relation to productive knowledge in general, the best estimate we have is that by Nation (1990), who claims that L2 or FL learners at tertiary level need productive knowledge of at least the most frequent 3,000 words. The present study builds on this assumption and aims to test the productive knowledge of collocations of first-year students at North-West University. Even though collocations are not the only aspect of productive vocabulary, researchers agree that they constitute an important part of productive knowledge (Ellis 2001, Nation 2001, Pawley and Syder 1983, Wray 2002) and are challenging for L2 learners (Laufer and Waldman 2011, Nesselhauf 2005, Wray 2002). In addition, appropriate language use requires knowledge of collocations, namely knowing the words with which a particular word collocates or combines (Ellis 2001, Nation 2001). 


\section{Related literature}

\subsection{Approaches to collocations}

L2 and FL practitioners and researchers agree that collocations constitute an important component of the vocabulary of any language (Barfiel and Gyllstad 2009) and, for this reason, they have increasingly received attention from researchers. Even though collocations have been approached differently in terms of what they consist of, many researchers have stressed their importance in language, especially in achieving fluent speech and writing, amongst other things (Barfield and Gyllstad 2009, Ellis 2001, Nation 2001, Pawley and Syder 1983, Wray 2002). The available literature points to three approaches to collocations (Gyllstad 2007, Granger and Paquot 2008, Handl 2008, Nesselhauf 2005, Siyanova and Schmitt 2008). The frequency-based and phraseological approaches are considered the two main ones, while a third approach (a blend of the first two) is emerging (Barfield and Gyllstad 2009, Gyllstad 2007, Granger and Paquot 2008, Nesselhauf 2005).

The frequency-based approach considers co-occurrence of collocation constituents as the main criterion according to which collocations should be defined (see Granger and Paquot 2008, Gyllstad 2007, Halliday 1966, Handl 2008, Li and Schmitt 2009, Nesselhauf 2005, Siyanova and Schmitt 2008, amongst others). This approach is attributed to Firth, who is widely regarded as having pioneered the study of collocations. Firth considers collocation potential as part of the meaning of a word, as he states that "[y]ou shall know a word by the company it keeps" (Firth 1957:179). A number of Neo-Firthians, particularly Halliday and Sinclair, adopted and expanded upon Firth's theory. Halliday (1966) built on Firth's idea and defined collocations as lexical items which co-occur at a distance from each other. Within this approach, collocation constituents co-occur at a frequency greater than chance would predict (Halliday 1966). Halliday (1996) also introduced new concepts such as 'node' (the main word in a collocation), 'collocate' (the co-occurring word) and 'span' (the distance within which collocation constituents co-occur). Concerning the latter, Sinclair (1991) suggested that a collocate can span or occur within a distance of about four words from the node.

The phraseological approach to collocations has Cowie (1998) and Howarth (1998) as its two main proponents. This approach was heavily influenced by Russian phraseology and suggests defining collocations on the basis of the syntactic categories of their constituents, the transparency of the collocation, and the degree of substitutability of the constituents (Granger and Paquot 2008, Gyllstad 2007, Li and Schmitt 2009, Nesselhauf 2005). In other words, the lexical items forming a collocation must be syntactically related and transparent in meaning, which implies that it is not any combination that is acceptable as a collocation. While verbnoun $(\mathrm{V}+\mathrm{N})$ combinations, such as draw a conclusion, or come to a conclusion, are frequent in English, adverb-noun combinations do not form collocations in this language. The verb draw/come to can be replaced with e.g. reach or arrive at but not with e.g. produce or achieve, which means that while substitution is possible, it is restricted. As opposed to the frequencybased approach, the phraseological approach considers the degree of substitutability and opacity in meaning as more important than the frequency of co-occurrence (Barfield and Gylstad 2009, Nesselhauf 2005).

As far as the third approach is concerned, it reconciles the two other approaches and retains elements from both in an attempt to overcome their respective limitations (Granger and Paquot 
2008, Gyllstad 2007, Nesselhauf 2005). Gyllstad (2007) and Granger and Paquot (2008) refer to this approach as the "best of the two worlds". The present study favours the third approach and adopts the following as the operational definition of "collocation": "the way words combine in a language to produce natural-sounding speech and writing" (Lea, Crowther and Dignen 2002:vii).

\subsection{Testing productive knowledge of collocations}

Productive knowledge of collocations has been tested through corpus analysis or elicitation (see Gyllstad 2007 and Nesselhauf 2005 amongst others). The present study falls within the second category, and this section briefly reviews the readily available productive tests of collocations.

Collocation tests were mainly designed to assess the general knowledge of collocations (Farghal and Obiedat 1995, Jaén 2007). To this end, translation, cloze and fill-in/sentencecompletion task types have been used, either separately or combined, in the same test battery. A general observation common to these studies is that learners at tertiary level have a poor grasp of collocations, which is an indication that "students may fall short in the social and academic demands made on their command of [their] L2" (Jaén 2007:143). In addition, in cases where receptive and productive knowledge is compared (Jaén 2007), the amount of productive knowledge is lower than that of receptive. This is to be expected, and confirms that collocations are more problematic at the productive level (Jaén 2007). The influence of the mother tongue in mastering L2 collocations has also been investigated, with the observation that closeness between L1 and L2 structure is a significant factor in collocational knowledge (Biskup 1992, Granger 1998).

Other studies attempted to establish a relationship between collocational competence and overall proficiency. These include Bonk (2001), Eyckmans et al. (2004), Gitsaki (1999) and Nizonkiza (2012b). Bonk (2001) tested collocational knowledge of university students using a fill-in task. In his study, collocational knowledge correlated significantly with an adapted version of the Test of English as a Foreign Language (TOEFL), which allowed him to conclude that knowledge of collocations develops in correlation with proficiency. Likewise, Eyckmans et al.'s (2004) Delete-Essentials Test (DET) proved that knowledge of collocations also develops in correlation with overall proficiency. The DET presents learners with authentic texts, where the target words (or collocates) are deleted and have to be inferred from the context and supplied. Since it is a cloze test, productive knowledge of collocations was able to be tested beyond mere word recognition (Boers and Lindstromberg 2009). It was found that the test scores correlated with the overall proficiency of participants, and the test could henceforth be viewed as a general proficiency indicator.

A similar observation was made by Gitsaki (1999) and Nizonkiza (2012b). Gitsaki (1999) tested the collocational knowledge of Greek learners of English, using both translation and fill-in tasks. One of her major findings was that knowledge of collocations develops in correlation with general proficiency. Nizonkiza (2012b) measured the collocational knowledge of English majors in Belgium and in Burundi, using a sentence-completion task. He involved participants from different academic levels (from first year through fourth year in Burundi, and first year and master's in Belgium). These students sat the same collocation test as was used in the present study (see section 3.2 for a description) as well as the TOEFL, of which the latter was used as a proficiency measure. Results of his study also indicate that collocational competence develops 
with overall proficiency, which implies that collocational competence can be a reliable indicator of L2 proficiency. Nizonkiza (2012b) also observed that gains in terms of collocations from one level of proficiency to another, as indicated by TOEFL, can be quantified and depend on both proficiency and word-frequency levels.

The studies described in the previous paragraphs were conducted using different tasks, and involved learners from various backgrounds. What is striking, however, is that all of them established a relationship between growth of collocational knowledge and overall proficiency. This is an important finding which can be further investigated in order to shed more light on the role of collocational competence at tertiary level. This insight can then assist in determining how much collocational knowledge is needed in order for students to cope with academic demands.

\section{Methodology}

\subsection{Participants}

Participants in the present study involved first-year students at North-West University's Potchefstroom campus. The first group $(\mathrm{N}=53)$ comprised students who were enrolled in an introduction to academic literacy course (AGLE 111) that was presented in English. While most of these participants' other subjects are presented in English, some are also presented in Afrikaans; in the case of the latter, simultaneous interpretation is then utilised. The participants speak different home languages, mainly Tswana, but all of them use English as their L2. The second group of participants $(\mathrm{N}=74)$ consisted of students who registered for different degrees, such as engineering, natural sciences, law and commerce, and who were enrolled in an introduction to academic literacy course presented in Afrikaans (AGLA 111). Afrikaans is their home language, and all of them are English L2 users who can be considered adept bilinguals. Most of their classes are presented in Afrikaans; however, if these classes are not available in this language, they attend the English lectures where they sometimes make use of the interpretation services offered by the university. Both groups have additional exposure to English through media such as newspapers, the internet, TV and radio.

\subsection{Instrument}

For the purpose of this study, participants sat a productive test of collocations modelled on Laufer and Nation (1999). As described in Nizonkiza (2012b), the collocation test (see Appendix B) was developed with target words selected from Nation's (2006) word-frequency list and the Academic Word List (Coxhead 2000). Nizonkiza (2012b:74) only retained V+N combinations, for the following reasons (note that the first three reasons are explained in Gyllstad (2007), while the fourth reason is provided in Lea et al. (2002)):

(a) they constitute frequent occurrences, (b) they are very difficult for L2 learners, and (c) they contain the most important information for communication. The fourth reason is that when we express ourselves, we do not think of the verb first. We tend to start with the noun [involved in] the action we want to do and then think of a verb which [is suitable to go] with it, [namely, a verb which describes] how to do the action. 
Nation's (2006) word-frequency list is a database of word families ${ }^{1}$ which is based on the British National Corpus. It originally consisted of 14 frequency bands ${ }^{2}$, each of which totals 1,000 words. For testing purposes, the researchers considered the 2000-word, 3000-word, 5000word and 10000-word bands. However, the 10000-word band was excluded from the sample since it consists of words deemed too infrequent to allow us to learn much from L2 students' test scores from this band (cf. Nizonkiza 2012b and Zhong and Hirsh 2009). The Academic Word List (Coxhead 2000) consists of words which do not appear in the 2,000 most frequent words, but which are frequent in academic texts. It consists of 570 word families compiled from a corpus of 3.5 million running words from written academic texts.

To select test items, Nation and Beglar's (2007) suggestion to retain 10 words from each frequency band was adopted. In the present case, 10 nouns were selected from each of the wordfrequency bands using systematic random sampling (cf. Babbie 1990). This sampling technique involves selecting every $\mathrm{n}^{\text {th }}$ word (in this case, every $100^{\text {th }}$ word) from a random starting point.

Once the target words had been selected, the next step was to select their verb collocates from the "Oxford Collocations Dictionary for Students of English" (Lea et al. 2002). The procedure was to look up each noun in this dictionary and then to find verbs collocating with it in the $\mathrm{V}+\mathrm{N}$ combination. In line with Gyllstad's (2007) suggestion that, for assessment purposes, collocates have to belong to the same or higher frequency bands than target words, the next step was to check the collocates against Nation's (2006) word-frequency list. Collocates which were less frequent than the target words were replaced. The last step was to determine the strength of the collocations, which was done through an online collocation sampler that gives different collocates of the node and determines how strongly they collocate. The most significant collocate was then retained. The test was modelled on the active version of Laufer and Nation's (1999) Vocabulary Levels Test, which is a controlled productive knowledge test. According to Laufer and Nation (1999:37), controlled productive knowledge is

the ability to use a word when compelled to do so by a teacher or researcher, whether in an unconstrained context such as a sentence writing task, or in a constrained context such as a fill in task where a sentence context is provided and the missing target word has to be supplied.

Laufer and Nation (1999) suggest deleting the tested items and instructing test-takers to supply them. For the purpose of the test in the present study, each collocate was deleted but the first two letters were provided in order to avoid widely varying answers (cf. Laufer and Nation 1999). These letters were underlined and, for clarity, test-takers were provided with an example (see below). The sentential contexts in which the words were embedded were taken from the collocation dictionary.

Instruction: Complete the underlined words in the sentences below.

Example: $\quad$ She is conducting campaigns to at....... new clients.

She is conducting campaigns to attract new clients.

\footnotetext{
${ }^{1}$ Here, "word families" refers to head words and their family members. For instance, the head word approach has as its family members various derivatives and inflections such as approachable, approached, approaches, approaching and unapproachable.

2 The frequency list has since been updated and now consists of 25 frequency bands.
} 


\section{Findings}

\subsection{Item analysis}

Language-testing experts agree that a well-functioning test should be reliable or, put differently, should consistently measure what it is designed to measure (cf. Alderson, Clapham and Wall 1995, Bachman 1990 amongst others). Cronbach's Alpha, which measures the internal consistency of a test, is widely used to this end. In the present study, Cronbach's Alpha was computed and shows a high reliability coefficient of .82. Following Pallant's (2007) recommendation that an Alpha of .7 is acceptable, the test can be considered internally consistent and therefore reliable. The items were also analysed in terms of their discriminating power by carrying out the Corrected Item-Total Correlation (CITC). Ideally, "good" items should discriminate between test-takers who perform differently. The CITC is measured on a scale of -1 to +1 and the higher the figure, the better the item discriminates between test-takers. The items' CITC coefficients were weighed against Ebel's (1979) scale in which .40 and higher indicates definitely good items, .30 to .39 indicates reasonably good items, .20 to .29 indicates marginal items in need of improvement, and items below .19 are poor and need to be revised or eliminated. The results are presented in Table 1, which summarises the information in Appendix A.

Table 1. Corrected Item-Total Correlation (CITC) on Ebel's (1979) scale

\begin{tabular}{|c|c|c|c|c|}
\hline CITC & $\begin{array}{l}.40 \text { and higher } \\
\text { (definitely } \\
\text { good items) }\end{array}$ & $\begin{array}{l}.30 \text { to } .39 \text { (reasonably } \\
\text { good items) }\end{array}$ & $\begin{array}{l}.20 \text { to } .29 \text { (items in } \\
\text { need of } \\
\text { improvement) }\end{array}$ & $\begin{array}{l}\text { Below .19 (poor } \\
\text { items to be revised } \\
\text { or eliminated) }\end{array}$ \\
\hline $\begin{array}{c}\text { Item } \\
\text { number }\end{array}$ & $4,11,27,36$ & $\begin{array}{l}7,8,13,17,18,19,20, \\
21,26,28,30,31,32, \\
33,34,35,39,40\end{array}$ & $\begin{array}{l}2,3,5,6,10,14,22 \\
23,24,25,37,38\end{array}$ & $1,9,12,15,16,29$ \\
\hline $\begin{array}{l}\text { Total } \\
\text { items }\end{array}$ & $4(10 \%)$ & $18(45 \%)$ & $12(30 \%)$ & $6(15 \%)$ \\
\hline
\end{tabular}

As reported in Table 1, six items (15\%), fall below Ebel's (1979) cut-off point of .19 and therefore have to be revised or eliminated. It is worth noting that only four of these items ( 9 , 12, 16, and 29) negatively affect the Alpha in that, if they are removed, the Alpha increases, as can be seen in column five of Appendix A. What this implies is that these items contribute to lowering the Alpha and thus do not perform well. However, as many as 34 items out of 40 (85\%) perform well, with values above Ebel's (1979) cut-off point of .19, therefore adding to the reliability of the test items.

\subsection{Productive knowledge of collocations achieved by tertiary-level L2 users of English}

Before answering the question examined in the present study, consider Figure 1 which provides a clear idea of the participants' scores which, it is evident, are close to a normal distribution. 


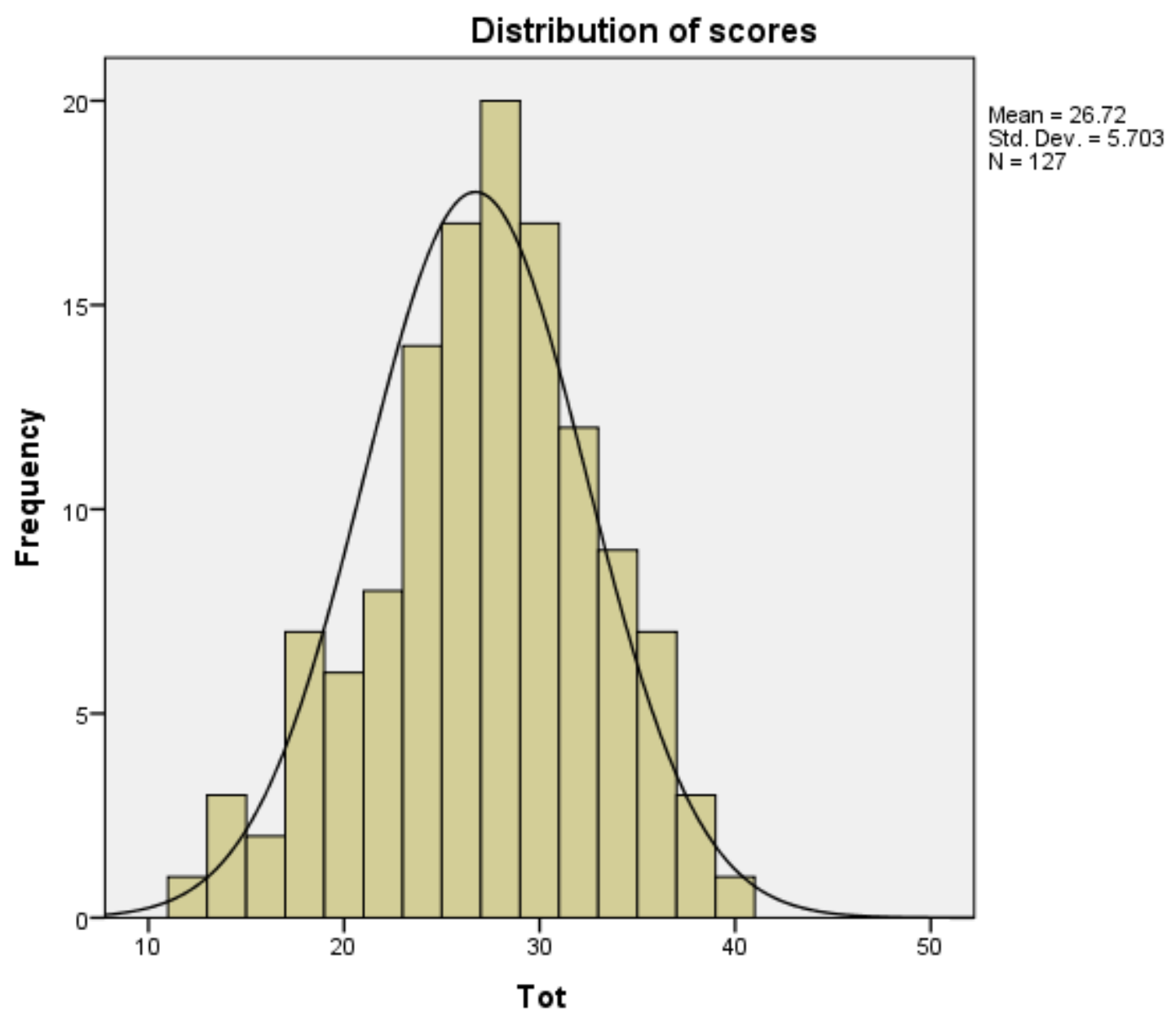

Figure 1. Score frequency distribution

After testing the distribution, we turned our attention to the fundamental aim pursued in this study, namely measuring productive knowledge of $\mathrm{V}+\mathrm{N}$ collocations of tertiary-level users of English. This measurement was achieved by computing the means at all the word-frequency bands, the results of which are presented in Table 2. As could be expected, the score is higher at the 2000-word band, where students achieved a mean score of 8.00 out of 10 . The mean drops to 7.03 at the 3000-word band, while it drops even further to 6.65 and 5.50 at the Academic Word List- and 5000-word bands, respectively. The mean scores were then weighed against Schmitt's cut-off point (cf. Table 3). Schmitt (2003, in Xing and Fulcher 2007), suggests that the cut-off point for an acquired word-frequency band should be $80 \%{ }^{3}$ which means, in this case, a score of eight out of 10 . If one looks at the mean scores achieved by the participants, only the 2000-word band is mastered. Keeping in mind Nation's (1990) view that students need at least a productive size of 3,000 words in order to cope with academic demands at tertiary level, this would translate, in our case, to a score of at least eight out of 10 at the 3000 -word band. Considering the mean scores achieved at the different word-frequency bands, it is clear that the participants in our study fall slightly short of expectations.

\footnotetext{
${ }^{3}$ Xing and Fulcher's (2007) personal communication (in 2003) with Schmitt. Xing and Fulcher (2007:184) acknowledge that "[w]hile the basis for this assertion is not clear from published sources, it remains the basis for establishing vocabulary level in studies that use [tests such as the Vocabulary Levels Test]".
} 
Table 2. Means per word-frequency band

\begin{tabular}{|l|l|l|l|l|}
\hline Word-Frequency band & N & Mean & Std Error of Mean & Std Deviation \\
\hline 2000-word & 127 & 8.00 & .16 & 1.79 \\
\hline 3000-word & 127 & 7.03 & .14 & 1.63 \\
\hline AWL & 127 & 6.65 & .18 & 2.08 \\
\hline 5000-word & 127 & 5.50 & .15 & 1.75 \\
\hline
\end{tabular}

An in-depth analysis was also conducted, taking into account individual participants' scores, in order to determine how many achieved above or below $80 \%$ at each frequency band. The results are presented in Table 3.

Table 3. Percentage of students above/below the cut-off point (80\%)

\begin{tabular}{|l|l|l|}
\hline Frequency band & $\mathbf{8 0} \%$ and above & Below 80\% \\
\hline $\mathbf{2 0 0 0}$-word & $75(59.05 \%)$ & $52(40.9 \%)$ \\
\hline $\mathbf{3 0 0 0}$-word & $49(38.5 \%)$ & $78(61.4 \%)$ \\
\hline AWL & $42(33.07 \%)$ & $85(66.9 \%)$ \\
\hline $\mathbf{5 0 0 0}$-word & $10(7.8 \%)$ & $117(92.1 \%)$ \\
\hline
\end{tabular}

As can be seen in Table 3, almost $60 \%$ of the participants master the 2000 -word band, $38.5 \%$ master the 3000-word band, 33.07\% master the Academic Word List, and only $7.8 \%$ master the 5000 -word band. The analysis clearly shows that there is considerable variability amongst participants. Even the 2000-word band, for which the overall score obtained was eight out 10, does not seem to be mastered by all the participants, with $40.9 \%$ falling below the cut-off point. Furthermore, more than $60 \%$ of the participants do not master the 3000 -word band and the Academic Word List, with $61.4 \%$ and $66.9 \%$, respectively, falling below the cut-off point.

\section{Discussion}

The present study examines controlled productive knowledge of collocations among first-year university students who are L2 users of English. Participants sat a collocation test and their scores were weighed against Schmitt's (2003) cut-off point of 80\% and Nation's (1990) size of productive knowledge. Results indicate that, overall, only the 2000-word band is mastered. Furthermore, with regard to Nation's (1990) view that tertiary-level students should possess a productive knowledge of the 3,000 most frequent words, the results show that the participants of this study fall short of this expectation. While this finding supports previous findings that L2 and FL speakers of English are not sensitive to collocations, which may cause problems for them at advanced levels (cf. Laufer and Waldman 2011, Nesselhauf 2005 amongst others), it also complements these studies by attempting to map the scores onto the threshold level required for meeting the challenges of the tertiary academic environment.

Furthermore, the study provides a method of identifying students who fall above or below the cut-off point, the advantage of which could be the option to build a detailed profile of individual students in terms of their productive knowledge of collocations, and to suggest remedial strategies accordingly. Indeed, the results of the analysis show that some individual students may require more academic attention than others. For instance, individual scores show that even though the 2000 -word band is mastered overall, as many as $40.09 \%$ of the students still do not 
attain this level. Achievement at the 3000-word and Academic Word List levels is even more worrying. More than $60 \%$ of the students in this study do not reach Nation's (1990) suggested minimum threshold which, in our view, and considering these scores, does not seem to be attainable unless some sort of intervention takes place. Therefore, we argue in favour of helping students via intervention.

A possible option could be to adopt an awareness-raising approach in which collocations are taught explicitly (cf. Barfield 2009 amongst others). The approach should be adapted, as Nizonkiza (2012a) suggests, by selecting target words from the relevant frequency bands along with their collocations from a collocation dictionary like the "Oxford Collocations Dictionary for Students of English" (Lea et al. 2002). As stated earlier, we are aware that collocations are not the only aspect of productive knowledge, but the available literature indicates that they are among those which are problematic for L2 English users. We sincerely believe that, in this endeavour to explicitly teach collocations for productive use, focusing on the 3000 -word band and the Academic Word List could particularly benefit tertiary-level students. We also recommend helping some individual students to master the 2000 -word band.

\section{Conclusion}

The present study has measured the productive knowledge of collocations of first-year students at North-West University. This was carried out by means of a collocation test modelled on Laufer and Nation (1999), with words selected from Nation's (2006) word bands and Coxhead's (2000) Academic Word List. Results indicate that only the 2000-word band is mastered, with some students still not achieving complete mastery of this band. Considering Nation's (1990) threshold and his view that students should be able to master the 3000 -word band, it was found that the students in our study fall slightly short of expectations. Although these findings assist in answering the research question, they simultaneously raise interesting questions that are worth exploring in follow-up studies.

Firstly, we plan to compare these collocation scores with those of the Test of Academic Literacy Levels (TALL) to investigate whether knowledge of collocations develops in correlation with academic literacy. This would complement Nizonkiza (in preparation), who established a relationship between TALL results and collocation test scores on words selected from the Academic Word List. The merit of this study would be to find out whether the groups identified as "academically at-risk" by the TALL are also identified as such by their collocation test scores. We could therefore suggest specific collocations to teach, depending on the students' performances on the collocation test, in the same way that the TALL is used to influence the content of the academic literacy courses.

Secondly, expanding the study to include more students and continuing to refine the test could help to standardise the testing of productive knowledge of collocations. The test used in this study has been criticised due to the first two letters having been provided in each question of the completion task (see section 3.2). Also, in some sentences, more contextual information was provided, which may have had consequences for the test-takers' performances. To this end, we suggest replicating the study in three related substudies; the first could include the target nouns used in this study and the participants would be required to supply their collocations in the $\mathrm{V}+\mathrm{N}$ combination; the second substudy could include the test used in this study without the first two letters being provided in each question of the completion task; finally, the third 
substudy could include the test used in this study without any changes. Interpreting the test scores in an integrated manner would allow for an exploration of the relationship between free productive knowledge and controlled productive knowledge of collocations. In addition, the role of context, on the one hand, and the role of providing the first two letters, on the other, could be determined. Alternatively, a corpus-driven approach could be adopted where collocations are identified that were produced in a corpus of participants' written assignments. This collocation use could then be compared to these participants' scores in the present test. We believe that the results from these substudies could provide more insight into the growth of collocations, an important aspect of vocabulary, that has been proven to be important in achieving fluency or proficiency in both speaking and writing.

\section{References}

Alderson, J.C., C. Clapham and D. Wall. 1995. Language test construction and evaluation. Cambridge: Cambridge University Press.

Babbie, E.R. 1990. Survey research methods. California and Belmont: Wordsworth Company.

Bachman, L.F. 1990. Fundamental considerations in language testing. Oxford: Oxford University Press.

Barfield, A. 2009. Following individual L2 collocation development over time. In A. Barfield and H. Gyllstad (eds.) Researching collocations in another language. New York: Palgrave Macmillan. pp. 208-223.

Barfield, A. and H. Gyllstad (eds.) 2009. Researching collocations in another language. New York: Palgrave Macmillan.

Biskup, G.D. 1992. L1 influence on learners' rendering of English collocations: A Polish/ German empirical study. In P.J.L. Arnaud and H. Béjoint (eds.) Vocabulary and applied linguistics. London: Macmillan. pp. 85-93.

Boers, F., J. Eyckmans, J. Kappel, S. Stengers and M. Demecheleer. 2006. Formulaic sequences and perceived oral proficiency: Putting the Lexical Approach to the test. Language Teaching Research 10(3): 245-261.

Boers, F. and S. Lindstromberg (eds.) 2008. Cognitive approaches to teaching vocabulary and phraseology. Berlin: Mouton De Gruyter.

Boers, F. and S. Lindstromberg. 2009. Optimizing a lexical approach to instructed language acquisition. New York: Palgrave Macmillan.

Bonk, W.J. 2001. Testing ESL learners' knowledge of collocations. In T. Hudson and J.D. Brown (eds.) A focus on language test development: Expanding the language proficiency construct across a variety of tests. Honolulu: University of Hawaii Second Language Teaching and Curriculum Center. pp. 113-142. 
Cowie, A.P. (ed.) 1998. Phraseology. Theory, analysis, and applications. Oxford: Clarendon Press.

Coxhead, A. 2000. A new academic word list. TESOL Quarterly 34(2): 213-239.

Coxhead, A. 2008. Phraseology and English for academic purposes: Challenges and opportunities. In S. Granger and F. Meunier (eds.) Phraseology. An interdisciplinary perspective. Amsterdam: John Benjamins Publishing Company. pp. 149-161.

Daller, H., J. Milton and J. Treffers-Daller (eds.) 2007. Modelling and assessing vocabulary knowledge. Cambridge: Cambridge University Press.

Ebel, R.L. 1979. Essentials of education measurement. New Jersey: Prentice Hall.

Ellis, N. 2001. Memory for language. In P. Robinson (ed.) Cognition and second language instruction. Cambridge: Cambridge University Press. pp. 33-68.

Eyckmans, J. 2009. Toward an assessment of learners' receptive and productive syntagmatic knowledge. In A. Barfield and H. Gyllstad (eds.) Researching collocations in another language. New York: Palgrave Macmillan. pp. 139-152.

Eyckmans, J., F. Boers and M. Demecheleer. 2004. The Deleted-Essentials Test: An effective and affective compromise. Available online: www.hltmag.co.uk/nov04/mart04.htm (Accessed 18 May 2010).

Farghal, M. and H. Obiedat. 1995. Collocations: A neglected variable in EFL. International Journal of Applied Linguistics 33(4): 315-332.

Gitsaki, C. 1999. Second language lexical acquisition: A study of the development of collocational knowledge. San Francisco: International Scholars Publications.

Granger, S. 1998. Prefabricated patterns in advanced EFL writing: Collocations and formulae. In A.P. Cowie (ed.) Phraseology: Theory, analysis and applications. Oxford: Oxford University Press. pp. 145-160.

Granger, S. and M. Paquot. 2008. Disentangling the phraseological web. In S. Granger and F. Meunier (eds.) Phraseology. An interdisciplinary perspective. Amsterdam: John Benjamins Publishing Company. pp. 27-49.

Gyllstad, H. 2007. Testing English collocations. Unpublished PhD dissertation. Lund University.

Gyllstad, H. 2009. Designing and evaluating tests of receptive collocation knowledge: COLLEX and COLLMATCH. In A. Barfield and H. Gyllstad (eds.) Researching collocations in another language. New York: Palgrave Macmillan. pp. 153-170.

Halliday, M. 1966. Lexis as a linguistic level. In C. Bazell, J. Catford, M. Halliday and R. Robins (eds.) In memory of J.R. Firth. London: Longman. pp. 148-162. 
Handl, S. 2008. Essential collocations for learners of English. The role of collocational direction and weight. In F. Meunier and S. Granger (eds.) Phraseology in foreign language teaching and learning. Amsterdam: John Benjamins Publishing Company. pp. 43-66.

Howarth, P. 1998. Phraseology of second language proficiency. Applied Linguistics 19(1): 2444.

Jaén, M.M. 2007. A corpus-driven design of a test for assessing the ESL collocational competence of university students. International Journal of English Studies 7(2): 127-147.

Keshavarz, M. H. and H. Salimi. 2007. Collocational competence and cloze test performance: a study of Iranian EFL learners. International Journal of Applied Linguistics 17: 81-92.

Laufer, B. and P. Nation. 1999. A vocabulary size test of controlled productive ability. Language Testing 16(1): 33-51.

Laufer, B. and T. Waldman. 2011. Verb-noun collocations in second language writing: A corpus analysis of learners' English. Language Learning 61(2): 647-672.

Lea, D., J. Crowther and S. Dignen (eds.) 2002. Oxford collocations dictionary for students of English. Oxford: Oxford University Press.

Li, J. and N. Schmitt. 2009. The acquisition of lexical phrases in academic writing: A longitudinal case study. Journal of Second Language Writing 18(2): 85-102.

Louw, H. 2005. Really too very much: Adverbial intensifiers in Black South African English. Proceedings from the Corpus Linguistics Conference Series 1(1). Available online: http:///www.corpus.bham.ac.uk/pclc/ (Accessed 8 May 2013).

Meara, P. 2002. The rediscovery of vocabulary. Second Language Research 18(4): 393-407.

Nation, P. 1983. Testing and teaching vocabulary. Guidelines 5(1): 12-25.

Nation, P. 1990. Teaching and learning vocabulary. Rowley, MA: Newbury House.

Nation, P. 2001. Learning vocabulary in another language. Cambridge: Cambridge University Press.

Nation, P. 2006. How large a vocabulary is needed for reading and listening? Canadian Modern Language Review 63(1): 59-82.

Nation, P. and D. Beglar. 2007. A vocabulary size test. The Language Teacher 31(7): 9-13.

Nesselhauf, N. 2005. Collocations in a learner corpus. Amsterdam: John Benjamins Publishing Company.

Nizonkiza, D. 2012a. The relationship between lexical competence, collocational competence, and $\mathrm{L} 2$ proficiency. Unpublished $\mathrm{PhD}$ thesis. University of Antwerp. 
Nizonkiza, D. 2012b. Quantifying controlled productive knowledge of collocations across proficiency and word frequency levels. Studies in Second Language Learning and Teaching 2(1): 67-92.

Nizonkiza (in preparation). The relationship between productive knowledge of collocations and academic literacy in tertiary level students. The South African Association of Language Teachers (SAALT).

Pallant, J. 2007. SPSS survival manual. Buckingham and Philadelphia: Open University Press.

Pawley, A. and F.H. Syder. 1983. Two puzzles for linguistic theory: Nativelike selection and nativelike fluency. In J.C. Richards and R.W. Schmidt (eds.) Language and communication. London: Longman. pp. 191-227.

Schmitt, N. 1998. Measuring collocational knowledge: Key issues and an experimental assessment procedure. ITL Review of Applied Linguistics 119-120: 27-47.

Schmitt, N., D. Schmitt and C. Clapham. 2001. Developing and exploring the behaviour of two new versions of the Vocabulary Levels Test. Language Testing 18(1): 55-88.

Sinclair, J. 1991. Corpus, concordance, collocation. Oxford: Oxford University Press.

Siyanova, A. and N. Schmitt. 2008. L2 learner production and processing of collocation: A multi-study perspective. The Canadian Modern Language Review 64(3): 429-458.

Wray, A. 2002. Formulaic language and the lexicon. Cambridge: Cambridge University Press.

Xing, P. and G. Fulcher. 2007. Reliability assessment for two versions of Vocabulary Levels Tests. System 35(2): 182-191.

Zareva, A., P. Schwanenflugel and Y. Nikolova. 2005. Relationship between lexical competence and language proficiency. Studies in Second Language 27(4): 567-595.

Zhong, H. and D. Hirsh. 2009. Vocabulary growth in English as a foreign language context. University of Sydney Papers in TESOL 4: 85-113. 
Appendix A: Corrected Item-Total Correlation

Table 1. Item-Total Statistics

\begin{tabular}{|c|c|c|c|c|}
\hline & $\begin{array}{l}\text { Scale Mean if } \\
\text { Item Deleted }\end{array}$ & \begin{tabular}{|l}
$\begin{array}{l}\text { Scale Variance if } \\
\text { Item Deleted }\end{array}$ \\
\end{tabular} & \begin{tabular}{|l|} 
Corrected Item-Total \\
Correlation
\end{tabular} & $\begin{array}{l}\begin{array}{l}\text { Cronbach's Alpha if } \\
\text { Item Deleted }\end{array} \\
\end{array}$ \\
\hline it_- & 25.91 & 31.286 & .170 & .819 \\
\hline it_- & 26.07 & 30.701 & .203 & .819 \\
\hline $3^{-}$ & 26.21 & 30.026 & .293 & .817 \\
\hline $4_{-}$ & 26.30 & 29.211 & .435 & .811 \\
\hline $\begin{array}{l}\text { it_- } \\
5\end{array}$ & 25.95 & 30.903 & .241 & .818 \\
\hline $\begin{array}{l}\text { it_- } \\
6\end{array}$ & 25.88 & 31.343 & .223 & .819 \\
\hline $\begin{array}{l}\text { it_- } \\
7^{-}\end{array}$ & 26.31 & 29.770 & .328 & .816 \\
\hline $\begin{array}{l}\text { it_- } \\
8\end{array}$ & 26.06 & 30.028 & .359 & .815 \\
\hline it_- & 26.08 & 30.994 & .136 & .821 \\
\hline $\begin{array}{l}\text { it } \\
10\end{array}$ & 26.05 & 30.649 & .227 & .819 \\
\hline it $\overline{1}$ & 26.59 & 29.339 & .478 & .810 \\
\hline it & 25.91 & 31.674 & .033 & .822 \\
\hline$\frac{\text { it }}{13}$ & 26.46 & 29.743 & .343 & .815 \\
\hline it $1 \overline{4}$ & 26.13 & 30.206 & .285 & .817 \\
\hline it $\overline{1} \overline{5}$ & 25.90 & 31.474 & .122 & .820 \\
\hline it $1 \overline{6}$ & 25.97 & 31.555 & .042 & .823 \\
\hline it $\overline{7}$ & 26.06 & 30.132 & .341 & .815 \\
\hline it 18 & 26.52 & 29.664 & .374 & .814 \\
\hline $\begin{array}{l}\text { it } \\
19\end{array}$ & 26.06 & 30.068 & .355 & .815 \\
\hline $\begin{array}{l}\text { it } \\
20\end{array}$ & 25.89 & 31.051 & .332 & .817 \\
\hline $\begin{array}{l}\text { it } \\
21\end{array}$ & 25.88 & 31.105 & .345 & .817 \\
\hline
\end{tabular}




\begin{tabular}{|c|c|c|c|c|}
\hline $\begin{array}{l}\text { it } \\
22\end{array}$ & 26.24 & 30.345 & .227 & .819 \\
\hline it $\overline{3}$ & 26.48 & 30.315 & .236 & .819 \\
\hline $\begin{array}{l}\text { it } \\
2 \overline{4}\end{array}$ & 26.36 & 30.312 & .226 & .819 \\
\hline $\begin{array}{l}\text { it } \\
2 \overline{5}\end{array}$ & 26.67 & 30.668 & .232 & .818 \\
\hline it $\overline{6}$ & 26.06 & 29.926 & .388 & .814 \\
\hline $\begin{array}{l}\text { it } \\
27 \overline{7}\end{array}$ & 26.06 & 29.862 & .403 & .813 \\
\hline it & 25.94 & 30.465 & .388 & .815 \\
\hline $\begin{array}{l}\text { it } \\
29\end{array}$ & 26.80 & 31.715 & .021 & .822 \\
\hline it & 26.51 & 29.855 & .333 & .815 \\
\hline $\begin{array}{l}\text { it } \\
31\end{array}$ & 25.93 & 30.558 & .394 & .815 \\
\hline it & 26.65 & 30.323 & .302 & .816 \\
\hline it & 26.04 & 29.959 & .395 & .814 \\
\hline it & 25.94 & 30.663 & .342 & .816 \\
\hline it & 25.98 & 30.436 & .344 & .815 \\
\hline it & 26.20 & 29.223 & .457 & .811 \\
\hline it & 26.38 & 30.031 & .278 & .817 \\
\hline it & 26.29 & 30.097 & .268 & .818 \\
\hline it & 26.11 & 30.004 & .334 & .815 \\
\hline it & 26.35 & 29.498 & .378 & .814 \\
\hline
\end{tabular}




\section{Appendix B: V+N Collocation Test Sample}

Name:

\section{Universiteit \\ Antwerpen}

Level of study (year):

University:
Productive Vocabulary Test

Date:

Start hour:

End hour:

Instruction: Complete the underlined words in the sentences below.

Example: She is conducting campaigns to at. new clients.

She is conducting campaigns to attract new clients.

1. I ha............. no intention of changing jobs because I am happy where I am.

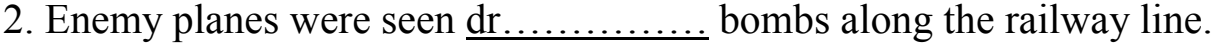

3 . They always pa............. a $10 \%$ commission on every sold encyclopaedia.

4. I wonder, this unusual building seems to barely fi............ the definition of a house.

5. Better sa............. your energy not trying to persuade people who are not interested.

6. She asked him if he could ke............ a secret before telling him the horrible story. 